\title{
Use of saccharose and structural polysaccharides from sugar beet biomass for bioethanol production**
}

 \\ Katarzyna Pielech-Przybylska®, Piotr Patelski®, and Katarzyna Robak® \\ Institute of Fermentation Technology and Microbiology, Faculty of Biotechnology \\ and Food Sciences, Łódź University of Technology, Wólczańska 171/173, 90-924 Łódź, Poland
}

Received July 25, 2019; accepted January 13, 2020

\begin{abstract}
A b stract. In addition to saccharose, sugar beet root contains a lignocellulosic fraction, which is not used in the process of sugar production and remains in sugar beet pulp. There is a great interest in using the polysaccharides (cellulose, hemicellulose) present in this raw material for the production of bioethanol. The objective of this study was to assess the effect of the enzymatic treatment of sugar beet biomass on the hydrolysis of the cellulose and hemicellulose present in its cell walls, as well as its effect on the efficiency of alcoholic fermentation of saccharose and sugars liberated from structural polysaccharides. Its effect on the efficiency of the process of inoculating the fermentation medium with a monoculture or a co-culture of yeast strains fermenting hexose and pentose sugars was also investigated. Our results reveal that in order to enable the utilization of all fermentable sugars in the sugar beet root biomass (saccharose as well as monosaccharides bound in structural polysaccharides), initial enzymatic treatment should be applied, followed by alcoholic fermentation using sequential inoculation with a co-culture of Saccharomyces cerevisiae and Pichia stipitis. These conditions ensure the utilization of hexoses and pentoses (xylose) in alcoholic fermentation, thus enabling the production of $9.9 \pm 0.4 \mathrm{~kg}$ of ethanol from $100 \mathrm{~kg}$ of sugar beet biomass.

Keywords: sugar beet, saccharose, structural polysaccharides, alcoholic fermentation, Saccharomyces cerevisiae, Pichia stipitis
\end{abstract}

\section{INTRODUCTION}

The European Union (EU) is the world's leading producer of sugar beet, accounting for approximately $50 \%$ of global production (European Seed Association, 2019). The sugar beet industry plays a critical part in the European

*Corresponding author e-mail: maria.balcerek@p.lodz.pl **This work was financed by a grant from NCBiR (Polish National Centre for Research and Development) implemented within the project BIOSTRATEG2/296369/5/NCBR/2016. agricultural economy, but recently sugar beet producers have been adversely affected by low market prices and a series of changes in the sector. The International Sugar Organization recently forecast that the EU will produce 17.9 million $t$ of sugar in the 2018/2019 season, down from 19.7 million $t$ in the previous season. In October 2017, the EU scrapped sugar beet production quotas, allowing producers to grow as much beet as they wanted for the first time since 2006. This led to an increase in output. However, the current global surplus of sugar has pushed world sugar prices down to their lowest level for more than ten years, thereby throwing the industry into crisis. Moreover, the European Commission is forecasting that total sugar consumption in the EU will be reduced by $5 \%$ by 2030 . The European Parliament must take many factors into consideration to maintain sustainable sugar beet production within the EU Member States (Sugar News \& Reports, 2019). One possible option is to use this raw material for other purposes, including the production of bio-based fuels and chemicals (Berłowska et al., 2016). In addition to saccharose, sugar beet also contains a lignocellulosic fraction, which is not used in traditional sugar production and remains in the sugar beet pulp (SBP). The polysaccharides present in SBP could be used for the production of bioethanol. Sugar beet pulp consists mainly of polysaccharides such as cellulose (22-30\%), hemicelluloses (24-32\%), lignin (1-2\%), and pectin (38-62\%), which constitute up to $75-85 \%$ of the dry matter (Micard et al., 1996). Before fermentation, the cell-wall material must be degraded into fermentable sugars (Alvira et al., 2010). Cellulose and hemicellulose can be hydrolysed down into simple sugars by cellulases or

(C) 2020 Institute of Agrophysics, Polish Academy of Sciences 
hemicellulases. Hexoses are fermented to ethanol by many naturally occurring microorganisms (Gong, 1983), including Saccharomyces cerevisiae, the most widely used yeast for ethanol production (Bai et al., 2008). However, S. cerevisiae is incapable of metabolizing xylose, and does not produce ethanol from it (Batt et al., 1986). Pentoses such as xylose and arabinose are fermented to ethanol by relatively few native strains, at relatively low yields (Gong, 1983). Some yeasts, such as Candida shehatae, Candida tropicalis, and Pichia stipitis, can ferment xylose and hexoses with relatively high yields (du Preez et al., 1986). However, they have a low ethanol tolerance (Rouhollah et al., 2007).

The production of ethanol from sugar beet offers a promising solution for sugar factories interested in combining the production of sugar and bioethanol. Using sugar beet as a raw material for bioethanol production is an especially attractive possibility for distilleries located near sugar factories, as they could minimize transportation costs. Cooperation between these factories and distilleries could lead to increased production and exploit the capacity of both types of facilities.

The aim of the present study was to examine the effect of the enzymatic treatment of sugar beet biomass on the hydrolysis of cellulose and hemicellulose present in its cell walls, and on the efficiency of alcohol fermentation from saccharose and other sugars liberated from the structural polysaccharides. The effect of inoculating the fermentation medium with different yeast strains on the efficiency of the process was also evaluated.

\section{MATERIALS AND METHODS}

Fresh sugar beet sliced into thin chips was obtained from the Dobrzelin Sugar Factory (Poland) and stored at $-20^{\circ} \mathrm{C}$ until used.

The sugar beet biomass was hydrolysed using an enzyme preparation, designated as IBT, originating from Aspergillus niger, containing cellulase $\left(3.81 \mathrm{U} \mathrm{ml}^{-1}\right)$, xylanase $\left(9.71 \mathrm{U} \mathrm{ml}^{-1}\right)$, and pectinase $\left(29.17 \mathrm{U} \mathrm{ml}^{-1}\right)$ (Institute of Molecular and Industrial Biotechnology, Łódź University of Technology).

Fermentation was carried out using two variants: 1) using only a preparation of Ethanol Red dry distillery yeast (S. cerevisiae) (Fermentis Division S.I. Lesaffre, France) at a dose of $0.5 \mathrm{~g} \mathrm{~d}$. m. $\mathrm{l}^{-1}$ of hydrolysate; 2) using a mixed culture of the S. cerevisiae strain ( $0.5 \mathrm{~g} \mathrm{~d} . \mathrm{m} . \mathrm{l}^{-1}$ of hydrolysate) and Pichia stipitis CBS 577 (ŁOCK 105, Łódź University of Technology, Poland) ( $3 \mathrm{~g} \mathrm{~d}$. m. l $^{-1}$ of hydrolysate), applied simultaneously or sequentially. With sequential inoculation, the process was initiated using Ethanol Red yeast $(0.5 \mathrm{~g}$ d.m. $\mathrm{l}^{-1}$ ) and after $36 \mathrm{~h}$ the hydrolysates were inoculated with P. stipitis $\left(3 \mathrm{~g} \mathrm{~d} . \mathrm{m} . \mathrm{l}^{-1}\right)$. The yeast Pichia stipitis was cultivated under conditions described in our previous work (Berłowska et al., 2016).

To prepare the hydrolysates for fermentation, sugar beet chips in the amount of $500 \mathrm{~g}$ were milled to obtain $0.8-1.0 \mathrm{~mm}$ particles, which were mixed with water in the ratio of 1:1 $\left(\mathrm{w} \mathrm{w}^{-1}\right)$. The mixture was stirred $(5 \mathrm{~min})$ by an overhead stirrer (CAT, R50) to obtain a homogenous semiliquid suspension. Next, the $\mathrm{pH}$ was adjusted to 4.8 using $25 \%\left(\mathrm{w} \mathrm{w} \mathrm{w}^{-1}\right)$ sulfuric acid and the suspension was subjected to the following types of processing (Table 1).

To determine the profile of fermentable sugars, depending on the enzyme preparation dose and hydrolysis conditions, a suspension was digested using 0.1 and $0.2 \mathrm{ml} \mathrm{g}^{-1}$ d.m. enzyme preparation. The samples were then maintained (without inoculation with yeast) under similar conditions as the fermented samples, i.e. at $35 \pm 2^{\circ} \mathrm{C}$ for $72 \mathrm{~h}$, when simultaneous saccharification fermentation or co-fermentation (SSF, SSCF ) took place, or at $50^{\circ} \mathrm{C}$ for $4 \mathrm{~h}$ or $24 \mathrm{~h}$ and then at $35 \pm 2^{\circ} \mathrm{C}$ for $72 \mathrm{~h}$ for processes carried out as separate hydrolysis/saccharification and (co-)fermentation (SHF, SHCF). In order to prevent microbial infections, the hydrolysates were supplemented with the antibiotics Penicillin G sodium salt (100 $000 \mathrm{U} \mathrm{kg}^{-1}$ hydrolysate) and Streptomycin sulfate salt $\left(0.1 \mathrm{~g} \mathrm{~kg}^{-1}\right.$ hydrolysate $)$.

Before fermentation, all trials were supplemented with $\left(\mathrm{NH}_{4}\right)_{2} \mathrm{HPO}_{4}\left(0.3 \mathrm{~g} \mathrm{~kg}^{-1}\right)$ as a source of nitrogen. Alcoholic fermentation was carried out in 21 glass flasks, each containing approximately $1 \mathrm{~kg}$ of hydrolysate. Before being added to the hydrolysate, Ethanol Red distillery yeast (S. cerevisiae) was first hydrated and acid-washed (15 min incubation of cells suspended in water with the addition of $25 \% \mathrm{w} \mathrm{w}^{-1}$ sulfuric acid solution, $\mathrm{pH} 2.5$, at room temperature). The yeast strain P. stipitis CBS 577 was added to the fermenting hydrolysates as a slurry without acid-washing. After inoculation with yeast, the flasks were closed with stoppers equipped with fermentation pipes, filled with glycerol, and stored in a thermostat-regulated room at $35 \pm 1{ }^{\circ} \mathrm{C}$. The process was monitored gravimetrically (to determine the decrease in mass caused by the liberation of carbon dioxide). When the fermentation process was complete (the entire process time for all samples did not exceed $72 \mathrm{~h}$ ), the samples were collected to determine the concentrations of ethanol, saccharose, hexose, and pentose sugars.

The sugar beet root was analysed according to methods recommended for the sugar industry (AOAC, 1995). Dry matter was determined in a Radwag WPS-30S moisture analyser. Total nitrogen was determined using the Kjeldahl method and converted into protein content using factor 6.25. Reducing sugars were determined according to the Miller method (1959) and expressed in grams of invert sugar per $\mathrm{kg}$ of sugar beet pulp. The concentration of saccharose was calculated as the difference between the amounts of total sugars determined after acid hydrolysis with hydrochloric acid and reducing sugars (both determined according to the Miller method), taking into consideration a conversion coefficient of 0.95. Cellulose content was determined according to the Kürschner-Hoffer method (1933), hemicellulose content according to the Ernakow method (Arasimovich and Ermakov, 1987) and lignin content according to the method recommended by the National Renewable Energy Laboratory (NREL) (Templeton and Ehrman, 1995). 
Table 1. Design of experiments for the enzymatic treatment and fermentation of sugar beet biomass

\begin{tabular}{|c|c|c|c|}
\hline Processing method & $\begin{array}{l}\text { Dose of enzyme preparation } \\
\text { and digestion conditions }\end{array}$ & Yeast & Designation of the sample \\
\hline Control sample & without enzymatic treatment & S. cerevisiae & Control S.c. \\
\hline \multirow{2}{*}{$\begin{array}{l}\text { Simultaneous } \\
\text { saccharification } \\
\text { and fermentation } \\
\text { (SSF) }\end{array}$} & $\begin{array}{l}0.1 \mathrm{ml} \mathrm{g}^{-1} \text { d.m., hydrolysis during } \\
\text { fermentation at } 35 \pm 1^{\circ} \mathrm{C}\end{array}$ & \multirow{2}{*}{$\begin{array}{l}\text { S. cerevisiae; an inoculation } \\
\text { with yeast immediately after } \\
\text { application of enzyme } \\
\text { preparations }\end{array}$} & SSF 0.1 IBT S.c. \\
\hline & $\begin{array}{l}0.2 \mathrm{ml} \mathrm{g}^{-1} \text { d.m., hydrolysis during } \\
\text { fermentation at } 35 \pm 1^{\circ} \mathrm{C}\end{array}$ & & SSF 0.2 IBT S.c. \\
\hline \multirow{4}{*}{$\begin{array}{l}\text { Separate } \\
\text { hydrolysis/ } \\
\text { saccharification } \\
\text { and fermentation } \\
\text { (SHF) }\end{array}$} & $\begin{array}{l}0.1 \mathrm{ml} \mathrm{g}^{-1} \text { d.m., hydrolysis at } 50^{\circ} \mathrm{C} \\
\text { for } 4 \mathrm{~h}\end{array}$ & \multirow{4}{*}{$\begin{array}{l}\text { S. cerevisiae; an inoculation } \\
\text { with yeast after enzymatic } \\
\text { hydrolysis }\end{array}$} & SHF 4 h 0.1 IBT S.c. \\
\hline & $\begin{array}{l}0.1 \mathrm{ml} \mathrm{g}^{-1} \mathrm{~d} . \mathrm{m} ., \text { hydrolysis at } 50^{\circ} \mathrm{C} \\
\text { for } 24 \mathrm{~h}\end{array}$ & & SHF 24h 0.1 IBT S.c. \\
\hline & $\begin{array}{l}0.2 \mathrm{ml} \mathrm{g}^{-1} \text { d.m., hydrolysis at } 50^{\circ} \mathrm{C} \\
\text { for } 4 \mathrm{~h}\end{array}$ & & SHF 4 h 0.2 IBT S.c. \\
\hline & $\begin{array}{l}0.2 \mathrm{ml} \mathrm{g}^{-1} \text { d.m., hydrolysis at } 50^{\circ} \mathrm{C} \\
\text { for } 24 \mathrm{~h}\end{array}$ & & SHF 24h 0.2 IBT S.c. \\
\hline \multirow{4}{*}{$\begin{array}{l}\text { Simultaneous } \\
\text { saccharification } \\
\text { and } \\
\text { co-fermentation } \\
\text { (SSCF) }\end{array}$} & $\begin{array}{l}0.1 \mathrm{ml} \mathrm{g}^{-1} \text { d.m., hydrolysis during } \\
\text { fermentation at } 35 \pm 1^{\circ} \mathrm{C}\end{array}$ & \multirow{2}{*}{$\begin{array}{l}\text { S. cerevisiae }+P \text {. stipitis; } \\
\text { simultaneous inoculation with } \\
\text { co-culture of yeast immediately } \\
\text { after application of enzyme } \\
\text { preparations }\end{array}$} & SSCF 0.1 IBT S.c.+P.s. sim \\
\hline & $\begin{array}{l}0.2 \mathrm{ml} \mathrm{g}^{-1} \mathrm{~d} . \mathrm{m} ., \text { hydrolysis during } \\
\text { fermentation at } 35 \pm 1^{\circ} \mathrm{C}\end{array}$ & & SSCF 0.2 IBT S.c.+P.s. sim \\
\hline & $0.1 \mathrm{ml} \mathrm{g}^{-1}$ d.m. & $\begin{array}{l}\text { S. cerevisiae }+ \text { P. stipitis; } \\
\text { sequential inoculation, initially } \\
\text { with yeast } S \text {. cerevisiae }\end{array}$ & SSCF 0.1 IBT S.c.+P.s. seq \\
\hline & $0.2 \mathrm{ml} \mathrm{g}^{-1}$ d.m. & $\begin{array}{l}\text { (immediately after application of } \\
\text { enzyme preparation) and next } \\
\text { after } 36 \mathrm{~h} \text { of fermentation (when } \\
\text { hexose sugars were almost } \\
\text { entirely utilized) with } \\
\text { P. stipitis }\end{array}$ & SSCF 0.2 IBT S.c.+P.s. seq \\
\hline \multirow{4}{*}{$\begin{array}{l}\text { Separate } \\
\text { hydrolysis/ } \\
\text { saccharification } \\
\text { and } \\
\text { co-fermentation } \\
\text { (SHCF) }\end{array}$} & $\begin{array}{l}0.1 \mathrm{ml} \mathrm{g}^{-1} \mathrm{~d} . \mathrm{m} . \text {, hydrolysis at } 50^{\circ} \mathrm{C} \\
\text { for } 4 \mathrm{~h}\end{array}$ & \multirow{2}{*}{$\begin{array}{l}\text { S. cerevisiae }+P \text {. stipitis; } \\
\text { simultaneous inoculation with } \\
\text { co-culture of yeast after } \\
\text { enzymatic hydrolysis }\end{array}$} & SHCF 4h 0.1 IBT S.c. + P.s. sim \\
\hline & $\begin{array}{l}0.1 \mathrm{ml} \mathrm{g}^{-1} \text { d.m., hydrolysis at } 50^{\circ} \mathrm{C} \\
\text { for } 24 \mathrm{~h}\end{array}$ & & SHCF 24h 0.1 IBT S.c.+P.s. sim \\
\hline & $\begin{array}{l}0.2 \mathrm{ml} \mathrm{g}^{-1} \mathrm{~d} . \mathrm{m} ., \text { hydrolysis at } 50^{\circ} \mathrm{C} \\
\text { for } 4 \mathrm{~h}\end{array}$ & \multirow{2}{*}{$\begin{array}{l}\text { S. cerevisiae }+ \text { P. stipitis; } \\
\text { sequential inoculation, initially } \\
\text { with yeast } S \text {. cerevisiae } \\
\text { (immediately after application of } \\
\text { enzyme preparation) and next } \\
\text { after } 36 \text { h of fermentation (when } \\
\text { hexose sugars were almost } \\
\text { entirely utilized) with } \\
P \text {. stipitis }\end{array}$} & SHCF 4 h 0.2 IBT S.c.+P.s. seq \\
\hline & $\begin{array}{l}0.2 \mathrm{ml} \mathrm{g}^{-1} \mathrm{~d} . \mathrm{m} ., \text { hydrolysis at } 50^{\circ} \mathrm{C} \\
\text { for } 24 \mathrm{~h}\end{array}$ & & SHCF 24 h 0.2 IBT S.c. + P.s. seq \\
\hline
\end{tabular}

The $\mathrm{pH}$ was also measured (with a digital $\mathrm{pH}$-meter). The contents of saccharose (SAC), glucose (GLC), fructose (FRU), galactose (GAL), xylose (XYL), arabinose (ARA), rhamnose (RHA), cellobiose (CEL), and raffinose (RAF) in the media before and after fermentation, as well as the content of ethanol after the completion of the fermentation process, were determined using HPLC as described by Berłowska et al. (2016).

Hydrolysis efficiency (HE) was calculated according to the following formula:

$$
H Y=\frac{C 0.9}{R S+S A C+R A F+P} 100 \%,
$$

where: $C$ is reducing pentose and hexose sugar concentration after hydrolysis $\left(\mathrm{g} \mathrm{kg}^{-1}\right), R S$ is the reducing sugars in sugar beet biomass before hydrolysis $\left(\mathrm{g} \mathrm{kg}^{-1}\right) ; S A C$ and $R A F$, are the saccharose and raffinose content $\left(\mathrm{g} \mathrm{kg}^{-1}\right)$ respectively; and $P$ is the polysaccharide (cellulose, hemicellulose) content $\left(\mathrm{g} \mathrm{kg}^{-1}\right) ; 0.9$ is the conversion coefficient 
from polysaccharide (cellulose and hemicellulose) to pentose and hexose sugars (i.e., the molecular weight ratio of polysaccharide to hexose and pentose sugars).

The fermentation efficiency $(F E)$ was calculated using a stoichiometric equation for hexose sugars (i.e. saccharose converted into invert sugar, glucose, fructose, and galactose) and pentose sugars (xylose) separately, and expressed as a percentage of the theoretical yield, according to the formula:

$$
F E=\frac{E}{F S 0.51} 100 \%,
$$

where: $E$ is the ethanol concentration in the fermented medium $\left(\mathrm{g} \mathrm{kg}^{-1}\right), F S$ is fermentable sugars (in the samples fermented with $S$. cerevisiae, the fermentation capacity was calculated from the hexose sugars, while in the samples fermented with a mixed culture of S. cerevisiae and P. stipitis, the content of hexose and pentose sugars was used), and 0.51 is the constant which represents the theoretical yield of ethanol from glucose and xylose. The ethanol yield was expressed as the amount of absolute ethanol $\left(\mathrm{A}_{100}\right)$ obtained from $100 \mathrm{~kg}$ of sugar beet biomass.

All samples were prepared and analysed in triplicate. The results were tested statistically by analysis of variance (one-way ANOVA), at a significance level of 0.05, using STATISTICA 10.0 software (StatSoft, Tulsa, OK, USA) to indicate differences.

\section{RESULTS AND DISCUSSION}

The chemical composition of the sugar beet used in this study is shown in Table 2. The main sugar present in sugar beet root is saccharose. Its content in the tested raw material was $536.36 \pm 42.90 \mathrm{~g} \mathrm{~kg}^{-1}$ d.m. Small amounts of reducing sugars $\left(21.89 \pm 1.31 \mathrm{~g} \mathrm{~kg}^{-1} \mathrm{~d}\right.$.m.) and raffinose $(6.86 \pm 0.45 \mathrm{~g}$ $\mathrm{kg}^{-1}$ d.m) were also detected. Sugar beet biomass is also a source of structural polysaccharides, which have great potential to be used in second generation bioethanol pro-

Table 2. Chemical composition of sugar beet root biomass

\begin{tabular}{lc}
\hline Physicochemical parameters & Content \\
\hline Dry mass $\left(\mathrm{g} \mathrm{kg}^{-1}\right)$ & $297.0 \pm 12.5$ \\
$\mathrm{pH}$ & $6.2 \pm 0.2$ \\
Reducing sugars as invert sugar $\left(\mathrm{g} \mathrm{kg}^{-1} \mathrm{~d} . \mathrm{m}.\right)$ & $21.89 \pm 1.31$ \\
Saccharose $\left(\mathrm{g} \mathrm{kg}^{-1} \mathrm{~d} . \mathrm{m}.\right)$ & $536.36 \pm 42.90$ \\
Raffinose $\left(\mathrm{g} \mathrm{kg}^{-1} \mathrm{~d} . \mathrm{m}.\right)$ & $6.86 \pm 0.45$ \\
Cellulose $\left(\mathrm{g} \mathrm{kg}^{-1} \mathrm{~d} . \mathrm{m}.\right)$ & $172.4 \pm 12.2$ \\
Hemicellulose $(\mathrm{g} \mathrm{kg}$ & $\mathrm{d} . \mathrm{m})$ \\
Lignin $\left(\mathrm{g} \mathrm{kg}^{-1} \mathrm{~d} . \mathrm{m}.\right)$ & $214.5 \pm 17.2$ \\
Protein $\left(\mathrm{N} \mathrm{x} \mathrm{6.25)}\left(\mathrm{g} \mathrm{kg}^{-1} \mathrm{~d} . \mathrm{m}\right)\right.$ & $1.42 \pm 0.36$ \\
\hline
\end{tabular}

Results expressed as mean values $\pm \operatorname{SE}(n=3)$. duction. A high content of cellulose and hemicellulose and a low content of lignin is advantageous from the technological point of view, since it promotes the production of high yields of fermentable sugars. However, the efficient hydrolysis and fermentation of these substrates depends on the type of pretreatment, the conditions of enzymatic hydrolysis, and on the microorganisms used for the fermentation of the released hexose and pentose sugars. Our results are similar to others reported in the literature (Wolak and Złocińska, 2012; Kühnel et al., 2011). Any differences in the chemical composition of the sugar beet biomass can be related to the varieties of sugar beet and cultivation conditions.

Various doses of the enzyme preparation IBT and hydrolysis conditions were investigated in order to determine their effects on the profile of fermentable sugars. Due to the fact that the tested feedstock contained a relatively low lignin content, experiments were carried out without thermochemical pretreatment, which is recommended to remove most of the lignin and facilitate the activity of cellulases and hemicellulases on structural polysaccharides (Pessoa et al., 1996, 1997). The aim of this stage of the study was to determine the amounts of sugars that could potentially be released under fermentation conditions (the samples were not inoculated with yeast).

The enzymatic hydrolysis of sugar beet-based medium with IBT preparation (at a dose of $0.1 \mathrm{ml} \mathrm{g}^{-1} \mathrm{~d} . \mathrm{m}$. sample I) under conditions prevailing during SSF and SSCF (i.e. a temperature of $35^{\circ} \mathrm{C}$ ) resulted in the release of the following amounts of sugars (per $\mathrm{kg}$ of hydrolysate): $35.22 \pm 1.75 \mathrm{~g}$ saccharose, $22.52 \pm 1.13 \mathrm{~g}$ glucose, $21.73 \pm$ $1.08 \mathrm{~g}$ fructose, $3.5 \pm 0.18 \mathrm{~g}$ galactose, $13.5 \pm 0.68 \mathrm{~g}$ xylose, $0.64 \pm 0.03 \mathrm{~g}$ arabinose, $0.49 \pm 0.02 \mathrm{~g}$ rhamnose, $0.71 \pm 0.04 \mathrm{~g}$ cellobiose, and $9.80 \pm 0.49 \mathrm{~g}$ raffinose (Fig. 1). The yield from the hydrolysis of polysaccharides in this medium was $68.90 \pm 1.38 \%$ (Fig. 2). A two-fold increase in the dose of enzymatic preparations, to $0.2 \mathrm{ml} \mathrm{g}^{-1} \mathrm{~d}$.m. (sample II), caused a relatively small rise (on average $15 \%$ ) in the glucose and fructose concentrations, to $26.18 \pm 1.83 \mathrm{~g} \mathrm{~kg}^{-1}$ and $24.80 \pm 1.74 \mathrm{~g} \mathrm{~kg}^{-1}$, respectively. Conversely, saccharose concentration dropped to $31.15 \pm 2.18 \mathrm{~g} \mathrm{~kg}^{-1}$, most likely due to its hydrolysis to glucose and fructose as a result of the side activity of the enzyme preparation used. Moreover, the increase in the concentration of xylose, from $13.5 \pm 0.95 \mathrm{~g} \mathrm{~kg}^{-1}$ to $14.7 \pm 1.03 \mathrm{~g} \mathrm{~kg}^{-1}$, was not significant $(p>0.05)$. In both samples, small amounts of galactose, arabinose, rhamnose, raffinose, and cellobiose were determined, as a result of the hydrolysis of non-starch polysaccharides (NSPs) (Lovegrove et al., 2017).

The next stage of the investigation focused on whether carrying out separate enzymatic hydrolysis at $50^{\circ} \mathrm{C}$ for $4 \mathrm{~h}$ or $24 \mathrm{~h}$ before fermentation would improve the release of fermentable sugars. It was observed that $4 \mathrm{~h}$ of incubation at an elevated temperature (samples III and IV) significantly $(p<0.05)$ improved the liberation of monosaccharides. 


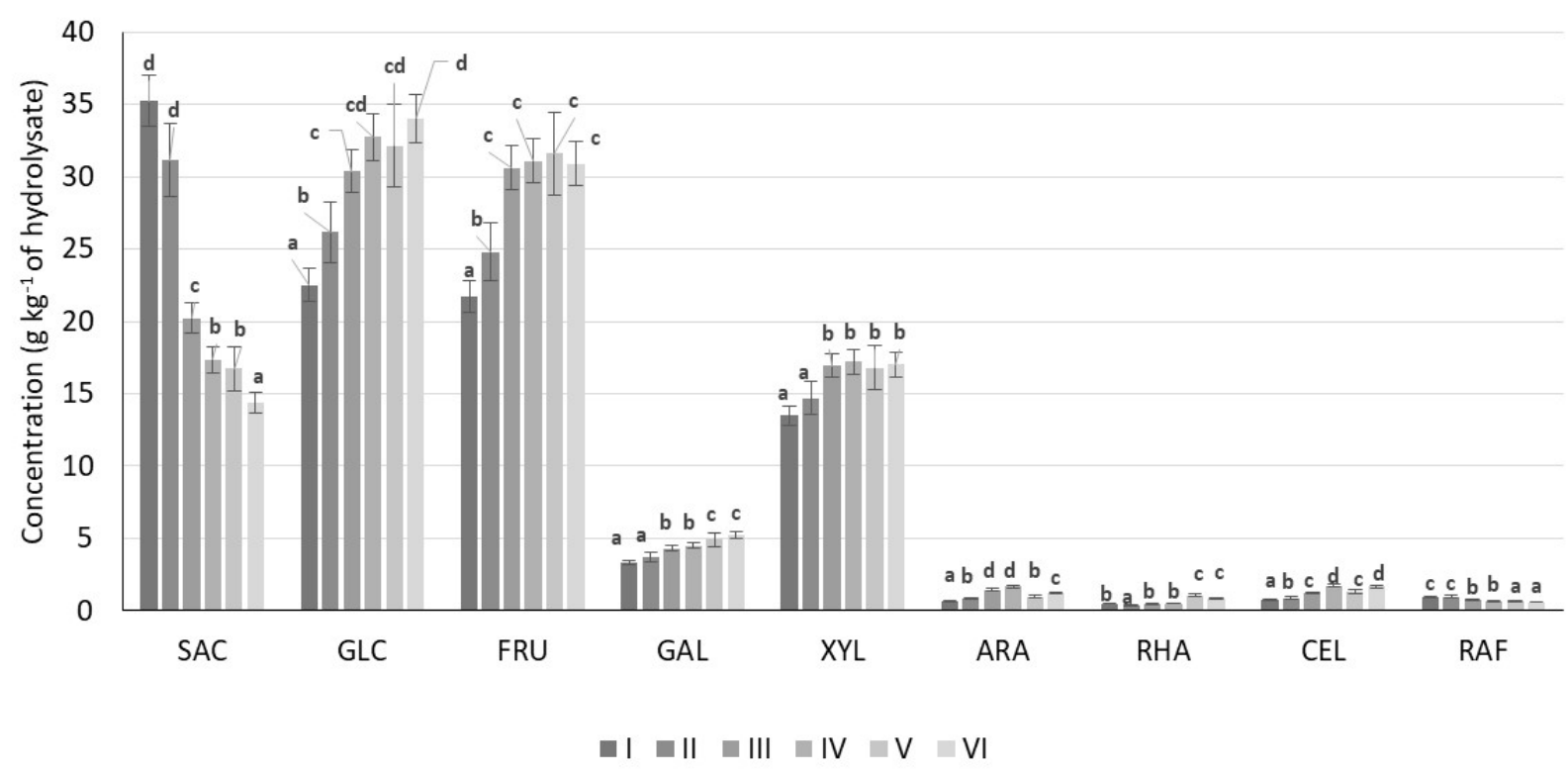

Fig. 1. Qualitative and quantitative composition of carbohydrates in sugar beet root biomass-based hydrolysates obtained after digestion of the feedstock with different doses of the enzyme preparation and under different conditions: $\mathrm{I}-0.1 \mathrm{ml} \mathrm{g}{ }^{-1} \mathrm{~d} . \mathrm{m}$., $35^{\circ} \mathrm{C}, 72 \mathrm{~h}$; $\mathrm{II}-0.2 \mathrm{ml} \mathrm{g}{ }^{-1}$ d.m., $35^{\circ} \mathrm{C}, 72 \mathrm{~h}$; III $-0.1 \mathrm{ml} \mathrm{g}{ }^{-1}$ d.m., $50^{\circ} \mathrm{C}, 4 \mathrm{~h}$ and then at $35^{\circ} \mathrm{C}$ for $72 \mathrm{~h}$; IV $-0.2 \mathrm{ml} \mathrm{g}{ }^{-1}$ d.m., $50^{\circ} \mathrm{C}, 4 \mathrm{~h}$ and then at $35^{\circ} \mathrm{C}$ for $72 \mathrm{~h}$; $\mathrm{V}-0.1 \mathrm{ml} \mathrm{g}{ }^{-1}$ d.m., $50^{\circ} \mathrm{C}, 24 \mathrm{~h}$ and then at $35^{\circ} \mathrm{C}$ for $72 \mathrm{~h}$; $\mathrm{VI}-0.2 \mathrm{ml} \mathrm{g}^{-1} \mathrm{~d} . \mathrm{m}$., $50^{\circ} \mathrm{C}, 24 \mathrm{~h}$ and then at $35^{\circ} \mathrm{C}$ for $72 \mathrm{~h}$. Mean values with different letters for each sugar content are significantly different $(\mathrm{p}<0.05)$.

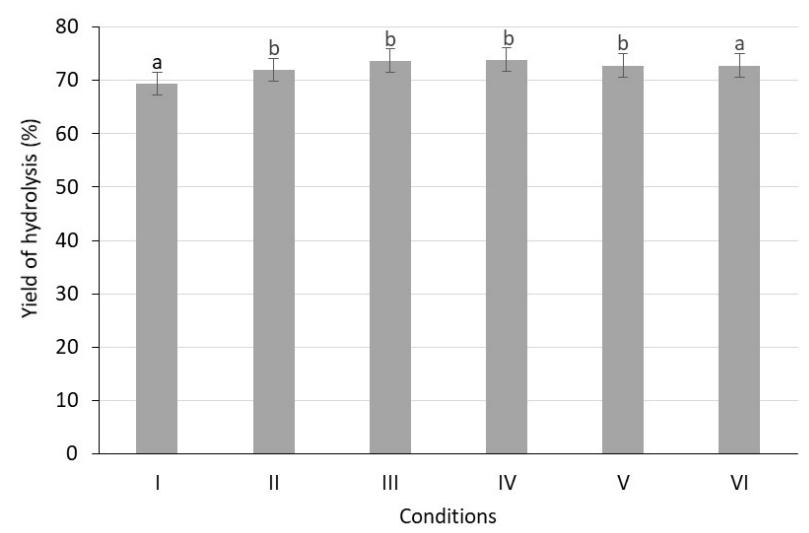

Fig. 2. Yield of hydrolysis of polysaccharides in sugar beet root biomass-based media. Explanations as in Fig. 1.

In turn, as with sample II, saccharose concentration in samples III and IV dropped to $20.24 \pm 1.42 \mathrm{~g} \mathrm{~kg}^{-1}$ and $17.34 \pm 1.21 \mathrm{~g} \mathrm{~kg}^{-1}$, respectively. The yield of polysaccharide hydrolysis in the tested samples was similar and ranged from $73.82 \pm 1.48 \%$ to $74.30 \pm 49 \%(\mathrm{p}<0.05)$. However, irrespective of the enzyme dose, the concentrations of hexoses reached similar values and ranged from 30.39 \pm 1.52 to $32.74 \pm 1.64 \mathrm{~g} \mathrm{~kg}^{-1}$ hydrolysate for glucose and from $30.6 \pm 1.53$ to $31.1 \mathrm{~g} \mathrm{~kg}^{-1}$ hydrolysate for fructose $(p<0.05)$. This suggests that a 2 -fold increase in the enzyme preparation dose does not cause a significant increase in the amounts of sugars liberated. Analogous observations were made with regard to other sugars, particularly xylose, which could be used by selected yeast strains in the process of alcoholic fermentation.
Prolonging the hydrolysis time at $50^{\circ} \mathrm{C}$ from 4 to $24 \mathrm{~h}$ did not result in a significant increase in the concentrations of fermentable sugars (samples V and VI). Also, saccharose concentrations did not show significant differences $(p<0.05)$ in relation to samples III and IV (Fig. 2). This may be due to the fact that when enzymatic hydrolysis is carried out as a separate step, it may lead to high concentrations of lower saccharides, which inhibit enzyme activity (Berłowska et al., 2016). In addition, it should be noted that increasing the time of hydrolysis at elevated temperatures generates higher energy inputs and raises the risk of microbial infections.

Based on our previous research, Ethanol-Red (S. cerevisiae) distillery yeast was applied to ferment the hexose sugars, while for the fermentation of pentoses (xylose) Pichia stipitis CBS 577 (ŁOCK 105, Łódź University of Technology, Poland) was used. In samples that were only fermented with $S$. cerevisiae, the lowest ethanol content $\left(30.57 \pm 0.53 \mathrm{~g} \mathrm{~kg}^{-1}\right.$ hydrolysate) and fermentation efficiency $(69.22 \pm 0.73 \%$ of the theoretical yield) was obtained for the control sample (without enzymatic treatment). The addition of IBT enzyme preparation $\left(0.1 \mathrm{ml} \mathrm{g}^{-1} \mathrm{~d}\right.$. m.) before inoculation with yeast resulted in an increase in ethanol content by approximately $2 \mathrm{~g} \mathrm{~kg}^{-1}$ hydrolysate, and as a consequence, fermentation efficiency rose to $73.57 \pm 1.06 \%$ of the theoretical limit $(p<0.05)$. It was observed that enzymatic treatment resulting in the hydrolysis of structural polysaccharides also affects the liquefaction of sugar beet biomass, which facilitates the availability of sugars to yeast and, as a consequence, improves the efficiency of fermentation. A two-fold increase in the dose of enzyme preparation 
followed by fermentation with $S$. cerevisiae did not cause a statistically significant improvement in the fermentation results $(\mathrm{p}>0.05)$ (Table 3$)$.

In the next stage of the study, the fermentation results were assessed for samples in which the separate hydrolysis of sugar beet biomass was performed with the enzyme preparation followed by fermentation with $S$. cerevisiae yeast (SHF). After $4 \mathrm{~h}$ of hydrolysis with a dose of $0.1 \mathrm{ml}$ $\mathrm{g}^{-1}$ d.m. enzyme preparation, the ethanol concentration in the hydrolysate reached $38.21 \pm 1.55 \mathrm{~g} \mathrm{~kg}^{-1}$ and the process efficiency was at $86.51 \pm 1.43 \%$ of the theoretical yield. Neither prolonging the hydrolysis time from 4 to $24 \mathrm{~h}$, nor doubling the enzyme preparation dose caused a significant improvement in the fermentation results $(p>0.05)$. However, there was a significant increase $(p>0.05)$ compared to the samples obtained using the SSF procedure (Table 3).
Two further series of experiments using the processing methods designated as simultaneous saccharification and co-fermentation (SSCF) and separate saccharification and co-fermentation (SHCF) were focused on the determination of the result of applying the hexose- and pentose-fermenting yeasts. Inoculation with the yeasts was carried out simultaneously or sequentially (i.e. initially with $S$. cerevisiae and then after $36 \mathrm{~h}$, when the hexose sugars were almost entirely consumed, with P. stipitis). Two doses of enzyme preparation were also tested, as well as the use (or omission) of initially separate hydrolysis. It was observed that the fermentation results for hexose sugars were similar for the majority of samples, with simultaneous or separate hydrolysis having no statistically significant effect $(\mathrm{p}>0.05)$. However, trials digested with $0.2 \mathrm{ml} \mathrm{g}^{-1} \mathrm{~d} . \mathrm{m}$. enzyme preparation and hydrolysed at $50^{\circ} \mathrm{C}$ for $4 \mathrm{~h}$ before sequential fermentation with $S$. cerevisiae and $P$. stipitis

Table 3. Fermentation factors of sugar beet root biomass-based hydrolysates

\begin{tabular}{|c|c|c|c|c|}
\hline \multirow{3}{*}{ Designation of the sample* } & \multicolumn{2}{|c|}{ Results for hexose sugars } & \multicolumn{2}{|c|}{ Results for pentose sugars } \\
\hline & $\begin{array}{l}\text { Ethanol content } \\
\text { of hydrolysate }\end{array}$ & $\begin{array}{c}\text { Fermentation } \\
\text { efficiency } \\
\text { of the theoretical } \\
\text { yield }\end{array}$ & $\begin{array}{l}\text { Ethanol content } \\
\text { of hydrolysate }\end{array}$ & $\begin{array}{c}\text { Fermentation } \\
\text { efficiency } \\
\text { of the theoretical } \\
\text { yield }\end{array}$ \\
\hline & $\left(\mathrm{g} \mathrm{kg}^{-1}\right)$ & $(\%)$ & $\left(\mathrm{g} \mathrm{kg}^{-1}\right)$ & $(\%)$ \\
\hline Control S.c. & $30.57 \pm 0.53 \mathrm{a}$ & $69.22 \pm 0.73 \mathrm{a}$ & - & - \\
\hline SSF 0.1 IBT S.c. & $32.53 \pm 0.89 b$ & $73.57 \pm 1.06 \mathrm{~b}$ & - & - \\
\hline SSF 0.2 IBT S.c. & $33.45 \pm 0.85 b$ & $75.74 \pm 1.12 b$ & - & - \\
\hline SHF 4h 0.1 IBT S.c. & $38.21 \pm 1.55 \mathrm{c}$ & $86.51 \pm 1.43 \mathrm{~cd}$ & - & - \\
\hline SHF 24h 0.1 IBT S.c. & $37.6 \pm 1.09 \mathrm{c}$ & $86.53 \pm 1.13 \mathrm{~d}$ & - & - \\
\hline SHF 4 h 0.2 IBT S.c. & $38.5 \pm 0.94 \mathrm{~cd}$ & $87.17 \pm 1.02 \mathrm{~cd}$ & - & - \\
\hline SHF 24h 0.2 IBT S.c. & $37.32 \pm 1.31 \mathrm{c}$ & $85.89 \pm 1.36 \mathrm{c}$ & - & - \\
\hline SSCF 0.1 IBT S.c. + P.s. sim & $37.74 \pm 1.54 \mathrm{~cd}$ & $86.84 \pm 1.61 \mathrm{~cd}$ & $1.43 \pm 0.22 \mathrm{a}$ & $20.43 \pm 0.31 \mathrm{a}$ \\
\hline SSCF 0.2 IBT S.c.+P.s. sim & $39.61 \pm 1.72 \mathrm{cde}$ & $89.59 \pm 1.89 \mathrm{def}$ & $2.07 \pm 0.18 \mathrm{~b}$ & $27.64 \pm 0.21 b$ \\
\hline SSCF 0.1 IBT S.c.+P.s. seq & $39.58 \pm 1.79$ cde & $89.51 \pm 1.88 \mathrm{def}$ & $5.04 \pm 0.34 \mathrm{~d}$ & $73.21 \pm 0.36 \mathrm{e}$ \\
\hline SSCF 0.2 IBT S.c.+P.s. seq & $40.61 \pm 1.77 \mathrm{de}$ & $91.84 \pm 2.03 \mathrm{fg}$ & $5.68 \pm 0.37 \mathrm{~d}$ & $75.80 \pm 0.38 f$ \\
\hline SHCF 4 h 0.1 IBT S.c. + P.s. sim & $39.59 \pm 1.89 \mathrm{cde}$ & $89.58 \pm 2.09 \mathrm{de}$ & $2.84 \pm 0.26 \mathrm{c}$ & $32.84 \pm 0.29 \mathrm{c}$ \\
\hline SHCF 24h 0.1 IBT S.c.+P.s. sim & $39.78 \pm 1.63 \mathrm{cde}$ & $89.98 \pm 1.45 \mathrm{e}$ & $2.94 \pm 0.24 \mathrm{c}$ & $34.36 \pm 0.27 \mathrm{~d}$ \\
\hline SHCF 4 h 0.2 IBT S.c. + P.s. seq & $41.56 \pm 1.58 \mathrm{e}$ & $93.12 \pm 1.68 \mathrm{~g}$ & $7.94 \pm 0.41 \mathrm{e}$ & $90.52 \pm 0.46 \mathrm{~h}$ \\
\hline SHCF 24 h 0.2 IBT S.c. + P.s. seq & $41.74 \pm 1.66 \mathrm{e}$ & $93.52 \pm 1.84 \mathrm{~g}$ & $7.55 \pm 0.44 \mathrm{e}$ & $87.74 \pm 0.48 \mathrm{~g}$ \\
\hline
\end{tabular}

*Detailed description of the samples - see Table 1. Results expressed as mean values \pm SE $(n=3)$; mean values in columns with different letters are significantly different $(\mathrm{p}<0.05)$. 
yeast showed an increase in the efficiency of the process (up to $93.12 \pm 1.68 \%$ of the theoretical limit). On the other hand, prolonging the time of separate hydrolysis from 4 to $24 \mathrm{~h}$ did not improve the fermentation efficiency of hexose sugars $(p>0.05)$, but rather entailed an unnecessary rise in thermal energy consumption and a greater risk of microbiological infections.

In the cases of both processing methods SSCF and SHCF, when a mixed culture of S. cerevisiae and P. stipitis was applied simultaneously, the lowest ethanol concentration $\left(1.43 \pm 0.22 \mathrm{~g} \mathrm{~kg}^{-1}\right.$ hydrolysate) produced from the pentose sugars was observed in the medium digested with $0.1 \mathrm{ml} \mathrm{g}^{-1} \mathrm{~d}$.m. enzyme preparation SSCF. The fermentation efficiency calculated from xylose only reached $20.43 \pm 0.31 \%$ of the theoretical yield. A two-fold increase in the dose of enzyme preparation caused a statistically significant $(p>0.05)$ increase in ethanol production, to $2.07 \pm 0.18 \mathrm{~g} \mathrm{~kg}^{-1}$ hydrolysate. However, the efficiency of xylose fermentation was still low and merely reached $27.6 \pm 0.21 \%$ of the theoretical value. Low ethanol contents, ranging from $2.84 \pm 0.26 \mathrm{~g} \mathrm{~kg}^{-1}$ hydrolysate $(4 \mathrm{~h}$ hydrolysis) to $2.94 \pm 0.24 \mathrm{~g} \mathrm{~kg}^{-1}$ hydrolysate ( $24 \mathrm{~h}$ hydrolysis) $(\mathrm{p}>0.05)$, were determined in the samples subjected to separate hydrolysis and co-fermentation (SHCF), and when S. cerevisiae and P. stipitis were added simultaneously. As a consequence, the fermentation efficiency of xylose was also low and ranged from $32.84 \pm 0.29 \%$ to $34.36 \pm 0.27 \%$ of the theoretical yield.

The García-Cubero et al. (2009) report revealed that carrying out a separate hydrolysis and fermentation with a monoculture of yeast SHF or co-fermentation with a mixed culture of microorganisms SHCF led to the accumulation of sugars released at the enzymatic hydrolysis stage, which resulted in the product-inhibition of enzymes and lower ethanol output. However, in our study, the most favourable variant, enabling the highest ethanol production from xylose, was the short $4 \mathrm{~h}$ separate enzymatic treatment $\left(0.2 \mathrm{ml} \mathrm{g}^{-1} \mathrm{~d}\right.$. m.) followed by fermentation with $S$. cerevisiae and $P$. stipitis applied sequentially. The ethanol concentration in this medium reached $7.94 \pm 0.41 \mathrm{~g} \mathrm{~kg}^{-1}$, while the fermentation efficiency calculated from xylose was $90.52 \pm 0.46 \%$ of the theoretical yield. Similar fermentation factors were observed when enzymatic pre-hydrolysis was prolonged to $24 \mathrm{~h}(\mathrm{p}>0.05)$ (Table 3). These results are in agreement with observations made by Berłowska et al. (2016) during studies concerning the alcoholic fermentation of sugar beet pulp, in which a $6 \mathrm{~h}$ enzymatic 'activation' before inoculation with yeast improved fermentation performance.

On the basis of the fermentation results in our study, we calculated the quantity of ethanol that could be obtained from $100 \mathrm{~kg}$ of sugar beet root biomass (Table 4). It was found that the lowest ethanol yield $(6.1 \pm 0.1 \mathrm{~kg}$ from $100 \mathrm{~kg}$ sugar beet biomass) was obtained when fermentation was carried out without enzymatic treatment, with $S$. cerevisiae. The digestion of the sugar beet biomass using IBT enzymatic preparation, especially as a separate hydrolysis step at $50^{\circ} \mathrm{C}$ for $4 \mathrm{~h}$, caused a statistically significant $(\mathrm{p}<0.05)$ increase in ethanol yield to $7.7 \pm 0.2 \mathrm{~kg}$ from $100 \mathrm{~kg}$ of sugar beet biomass. The only sugars utilized in these trials were hexoses. The application of a yeast able to ferment pentose sugars (especially xylose) liberated after enzymatic treatment resulted in the production of ethanol from xylose, and as a consequence an increase in its yield. The most favourable conditions for ethanol production established in our experiments are as follows: initial $4 \mathrm{~h}$ separate digestion of biomass with IBT enzymatic preparation at a dose of $0.2 \mathrm{ml} \mathrm{g}^{-1} \mathrm{~d}$.m., and then fermentation with a co-culture of $S$. cerevisiae and P. stipitis, applied sequentially. Such conditions ensure that both hexoses and pentoses (xylose) are utilized in the fermentation process. It was found that $9.9 \pm 0.4 \mathrm{~kg}$ (i.e. 12.6 l) of absolute ethanol can be produced from $100 \mathrm{~kg}$ of sugar beet biomass under these conditions (Table 4). By comparison, Gumienna et al. (2014) reported that alcoholic fermentation of sugar beet root pulp with S. cerevisiae (Safdistil C-70; $30^{\circ} \mathrm{C}, 72 \mathrm{~h}$ ) yielded up to 10.41 (i.e. approximately $8.2 \mathrm{~kg}$ ) of absolute ethanol from $100 \mathrm{~kg}$ of raw material. The differences in ethanol yield are most likely the consequence of the utilization of fermentable sugars liberated from structural polysaccharides in our experiments. The application of the proposed solution in industrial practice could contribute to an increase the efficiency of sugar beet biomass utilization and ethanol productivity, while also improving the nutritional value of distillery stillage resulting from the presence of yeast biomass. Another crucial issue is that biofuels, including bioethanol, are known to reduce the greenhouse gas (GHG) effect. The level of GHG emissions in the bioethanol life cycle depend on such factors as the raw material and production technology used. The usage of sugar beet-based ethanol is very favourable due to lowering GHG emission levels (Dziugan et al., 2013).

\section{CONCLUSIONS}

1. Apart from saccharose, sugar beet biomass contains structural polysaccharides such as cellulose and hemicellulose, which makes it an attractive raw material for the production of bioethanol.

2. In order to increase the utilization of saccharose as well as monosaccharides linked in structural polysaccharides, it is advisable to apply initial enzymatic treatment to the biomass. In this study, it was found that the most favourable conditions, enabling the highest ethanol production from hexose and pentose sugars, was separate hydrolysis and fermentation, where $4 \mathrm{~h}$ digestion of biomass with 0.2 $\mathrm{ml} \mathrm{g}^{-1} \mathrm{~d}$.m. IBT enzymatic preparation at $50^{\circ} \mathrm{C}$ was applied. 
Tab le 4. Ethanol yield ( $\mathrm{kg}$ absolute ethanol) from $100 \mathrm{~kg}$ of sugar beet root biomass

\begin{tabular}{|c|c|c|c|}
\hline \multirow{2}{*}{ Designation of the samples* } & \multicolumn{3}{|c|}{ Ethanol yield (kg absolute ethanol) } \\
\hline & from hexose sugars & from pentose sugars & sum \\
\hline Control S.c. & $6.1 \pm 0.1 \mathrm{a}$ & - & $6.1 \pm 0.1 \mathrm{a}$ \\
\hline SSF 0.1 IBT S.c. & $6.5 \pm 0.2 b$ & - & $6.5 \pm 0.2 b$ \\
\hline SSF 0.2 IBT S.c. & $6.7 \pm 0.2 b$ & - & $6.7 \pm 0.2 b$ \\
\hline SHF 4h 0.1 IBT S.c. & $7.6 \pm 0.3 \mathrm{c}$ & - & $7.6 \pm 0.3 \mathrm{c}$ \\
\hline SHF $24 \mathrm{~h} 0.1$ IBT S.c. & $7.5 \pm 0.2 \mathrm{c}$ & - & $7.5 \pm 0.2 \mathrm{c}$ \\
\hline SHF 4h 0.2 IBT S.c. & $7.7 \pm 0.2 \mathrm{c}$ & - & $7.7 \pm 0.2 \mathrm{c}$ \\
\hline SHF 24h 0.2 IBT S.c. & $7.5 \pm 0.3 \mathrm{c}$ & - & $7.5 \pm 0.3 \mathrm{c}$ \\
\hline SSCF 0.1 IBT S.c.+P.s. sim & $7.5 \pm 0.3 \mathrm{c}$ & $0.3 \pm 0.04 \mathrm{a}$ & $7.8 \pm 0.3 \mathrm{~cd}$ \\
\hline SSCF 0.2 IBT S.c.+P.s. sim & $7.9 \pm 0.3 \mathrm{~cd}$ & $0.4 \pm 0.04 \mathrm{~b}$ & $8.3 \pm 0.3 \mathrm{de}$ \\
\hline SSCF 0.1 IBT S.c.+P.s. seq & $7.9 \pm 0.3 \mathrm{~cd}$ & $1.0 \pm 0.07 \mathrm{~d}$ & $8.9 \pm 0.4 \mathrm{ef}$ \\
\hline SSCF 0.2 IBT S.c.+P.s. seq & $8.1 \pm 0.3 \mathrm{~d}$ & $1.1 \pm 0.07 \mathrm{~d}$ & $9.2 \pm 0.4 \mathrm{f}$ \\
\hline SHCF 4h 0.1 IBT S.c.+P.s. sim & $7.9 \pm 0.3 \mathrm{~cd}$ & $0.6 \pm 0.05 \mathrm{c}$ & $8.5 \pm 0.4 \mathrm{ef}$ \\
\hline SHCF 24 h 0.1 IBT S.c.+P.s. sim & $8.0 \pm 0.3 \mathrm{~cd}$ & $0.6 \pm 0.05 \mathrm{c}$ & $8.5 \pm 0.4 \mathrm{ef}$ \\
\hline SHCF 4 h 0.2 IBT S.c. + P.s. seq & $8.3 \pm 0.3 \mathrm{~d}$ & $1.6 \pm 0.1 \mathrm{e}$ & $9.9 \pm 0.4 \mathrm{~g}$ \\
\hline SHCF 24 h 0.2 IBT S.c. + P.s. seq & $8.3 \pm 0.3 \mathrm{~d}$ & $1.5 \pm 0.1 \mathrm{e}$ & $9.8 \pm 0.4 \mathrm{~g}$ \\
\hline
\end{tabular}

*Detailed description of the samples - see Table 1. Results expressed as mean values \pm SE $(n=3)$; mean values in columns with different letters are significantly different $(\mathrm{p}<0.05)$.

3. For the best possible results, the fermentation of hexose and pentose (xylose) sugars should be carried out using sequential inoculation with a co-culture of $\mathrm{S}$. cerevisiae and P. stipitis yeasts. Such conditions allow $9.9 \pm 0.4 \mathrm{~kg}$ (i.e. $12.6 \mathrm{l}$ ) of absolute ethanol to be obtained from $100 \mathrm{~kg}$ of sugar beet biomass.

Conflict of interest: The Authors declare no conflict of interest.

\section{REFERENCES}

Alvira P., Tomás-Pejó E., Ballesteros M., and Negro M.J., 2010. Pretreatment technologies for an efficient bioethanol production process based on enzymatic hydrolysis: a review. Biores. Technol., 101, 4851-4861. https://doi.org/10.1016/j.biortech.2009.11.093

AOAC Official Methods of Analysis of AOAC International, 1995. Vol. 2, AOAC Int., MD, USA,

Arasimovich V.V. and Ermakov A.I., 1987. Measurement of the total content of hemicelluloses. In: Methods for Biochemical Studies of Plants (Ed. A.I. Ermakov). Agropromizdat, Saint Petersburg, Russia.

Bai F.W., Anderson W.A., and Moo-Young M., 2008. Ethanol fermentation technologies from sugar and starch feedstocks. Biotechnol. Adv., 26, 89-105. https://doi.org/10.1016/j.biotechadv.2007.09.002
Batt C.A., Carvallo S., Easson D.D., Akado M., and Sinskey A.J., 1986. Direct evidence for a xylose metabolic pathway in Saccharomyces cerevisiae. Biotechnol. Bioeng., 28, 549553. https://doi.org/10.1002/bit.260280411

Berlowska J., Pielech-Przybylska K., Balcerek M., DziekońskaKubczak U., Patelski P., Dziugan P., and Kręgiel D., 2016. Simultaneous saccharification and fermentation of sugar beet pulp for efficient bioethanol production. BioMed Res., Article ID 3154929. https://doi.org/10.1155/2016/3154929

du Preez J.C., Bosch M., and Prior B.A., 1986. Xylose fermentation by Candida shehatae and Pichia stipitis: effects of $\mathrm{pH}$, temperature and substrate concentration. Enzyme Microb. Technol., 8(6), 360-364. https://doi.org/10.1016/0141-0229(86)90136-5

Dziugan P., Balcerek M., Pielech-Przybylska K., and Patelski P., 2013. Evaluation of the fermentation of high gravity thick sugar beet juice worts for efficient bioethanol production. Biotechnol. Biofuels, 6, 158. https://doi.org/10.1186/1754-6834-6-158

European Seed Association (ESA), 2019. Available from: https://www.euroseeds.eu/sugar-beet.

García-Cubero M.T., González-Benito G., Indacoechea I., Coca M., and Bolado S., 2009. Effect of ozonolysis pretreatment on enzymatic digestibility of wheat and rye straw. Biores. Technol., 100(4), 1608-1613. https://doi.org/10.1016/j.biortech.2008.09.012 
Gong C.S., 1983. Recent advances in D-xylose conversion by yeasts. Annual Reports of Fermentation Processes, 6, 253297. https://doi.org/10.1016/b978-0-12-040306-6.50015-8

Gumienna M., Szambelan K., Jeleń H., and Czarnecki Z., 2014. Evaluation of ethanol fermentation parameters for bioethanol production from sugar beet pulp and juice. J. Inst. Brew., 120, 543-549. https://doi.org/10.1002/jib.181

Kürschner K. and Hoffer A., 1933. Cellulose and cellulose derivatives. Fresenius' J. Anal. Chem., 92(3), 145-154.

Kühnel S., Schols H.A., Gruppen H., 2011. Aiming for the complete utilization of sugar-beet pulp: Examination of the effects of mild acid and hydrothermal pretreatment followed by enzymatic digestion. Biotechnol. Biofuels, 4, 14. https://doi.org/10.1186/1754-6834-4-14

Lovegrove A., Edwards C.H., De Noni I., Patel H., EI S.N., Grassby T., Zielke C., Ulmius M., Nilsson L., Butterworth P.J., Ellis P.R., and Shewry P.R., 2015. Role of polysaccharides in food, digestion, and health. Crit. Rev. Food Sci. Nutr., 57(2), 237-253. https://doi.org/10.1080/10408398.2014.939263

Micard V., Renard C.M., and Thibault J.F., 1996. Enzymatic saccharification of sugar-beet pulp. Enzyme Microb. Technol., 19, 162-170. https://doi.org/10.1016/0141-0229(95)00224-3
Miller G.L., 1959. Use of dinitrosalicylic acid reagent for determining reducing sugars. Anal. Chem., 31, 426-428. https://doi.org/10.1021/ac60147a030

Pessoa A., de Mancilha I.M., and Sato S., 1996. Cultivation of Candida tropicalis in sugar cane hemicellulosic hydrolyzate for microbial protein production. J. Biotechnol., 5, 83-88. https://doi.org/10.1016/0168-1656(96)01572-6

Pessoa A., de Mancilha I.M., and Sato S., 1997. Evaluation of sugar cane hemicellulose hydrolyzate for cultivation of yeasts and filamentous fungi. J. Ind. Microbiol. Biotechnol., 18, 360-363. https://doi.org/10.1038/sj.jim.2900403

Rouhollah H., Iraj N., Giti E., and Sora A., 2007. Mixed sugar fermentation by Pichia stipitis, Sacharomyces cerevisiae, and an isolated xylose fermenting Kluyveromyces marxianus and their co-cultures. Afr. J. Biotechnol., 6, 1110-1114.

SUGAR NEWS \& REPORTS, 2019. Available at: https://www.ragus.co.uk/eu-sugar-beet-production-whatdoes-the-future-hold/

Templeton D. and Ehrman T., 1995. Determination of acidinsoluble lignin in biomass. Chemical Analysis and Testing Task, Laboratory Analytical Procedure LAP-003. National Renewable Energy Laboratory (NREL), Golden, CO. https://doi.org/10.2172/1021264

Wolak P. and Zlocińska A., 2012. Examination of the chemical composition of sugar beet pulp - a by-product of sugar industry (in Polish). Eng. Sci. Technol., 2, 109-119. 